\title{
Angioma serpiginosum
}

INSERM

\section{Source}

INSERM. (1999). Orphanet: an online rare disease and orphan drug data base. Angioma serpiginosum. ORPHA:95429

Angioma serpiginosum (AS) is a benign congenital skin disease characterised by progressive dilation of the subepidermal skin vessels manifesting as purple punctate lesions usually appearing on the lower limbs and buttocks and following the lines of Blaschko. 